\title{
The Fifteenth-Century Councils: Francisco de Vitoria, Melchor Cano, and Bartolomé Carranza
}

\author{
THOMAS IZBICKI
}

Rutgers University

\begin{abstract}
The Dominican theologian Francisco de Vitoria, founder of the School of Salamanca, was cautiously positive about general councils as useful to the church. However, he was not supportive of the strong conciliarism of the University of Paris. Vitoria's successor at Salamanca, Melchor Cano, was much more a papalist, an opinion partially shared by Bartolomé Carranza, who attended the opening sessions of the Council of Trent (1545-63) and became archbishop of Toledo. Both Cano and Carranza rejected any claim to conciliar power over a reigning pope, although Carranza wrote more favourably about councils than did Cano. Their criticisms of the fifteenth-century councils of Constance (1414-18) and Basel (1431-49) foreshadowed the categorization of councils by Robert Bellarmine based on loyalty to the papacy. All of these theologians shared the belief that the ideal council was that of Ferrara-Florence (1438-45), which was summoned and directed by a pope.
\end{abstract}

Le théologien dominicain Francisco de Vitoria, fondateur de l'École de Salamanque, reconnaissait parcimonieusement l'utilité des conciles généraux envers l'Église. Cependant, il n'était pas en faveur du conciliarisme prononcé de l'Université de Paris. Le successeur de Vitoria à Salamanque, Melchor Cano, était beaucoup plus papiste, selon l'opinion généralement émise par Bartolomé Carranza, qui était présent lors des séances d'ouverture du Concile de Trente (1545-63) et qui est devenu l'archevêque de Tolède. Les deux hommes rejetaient toute revendication du pouvoir conciliaire sur un pape régnant, bien que, à travers ses écrits, Carranza ait dépeint les conciles de manière plus favorable que ne l'a fait Cano. Les critiques de Cano y Carranza des conciles de Constance (1414-18) et de Bâle (1431-49) au quinzième siècle anticipent la catégorisation des conciles par Robert Bellarmin basée sur leur loyauté envers la papauté. Le concile de Ferrare-Florence (1438-45), qui avait été organisé et dirigé par un pape, correspondait à leur représentation d'un concile valide.

The fifteenth-century councils-Pisa (1409), Constance (1414-18), Pavia-
Siena (1423-24), Basel (1431-49), and Ferrara-Florence (1438-45)resolved the Great Western Schism (1378-1417) and attempted church reform "in head and members." Constance had issued the decree Haec sancta, which claimed for general councils ultimate power in issues of heresy, schism, and reform. It also issued the decree Frequens, which required convoking general councils on a regular basis, eventually every ten years. ${ }^{1}$ Even those who rejected

1. Conciliorum Oecumenicorum Generaliumque Decreta, ed. Alberto Melloni and Davide Dainese, vol. 2 (Turnhout: Brepols, 2013), part 1, 548-50, 608-09. C. M. D. Crowder, Unity, Heresy and Reform, 
Constance's claim to ecclesiastical power had to embrace its condemnations of John Wyclif and Jan Hus. Thus, papalists had to walk carefully, accepting the council in some ways even if not in others. ${ }^{2}$

The reform agenda, advanced only partially at Constance and PaviaSiena, led the Council of Basel to attempt the deposition of Pope Eugenius IV (1431-47) in 1439 for his defiance of conciliar supremacy. Even with the defeat of the Council of Basel by the papacy, the issue of conciliar supremacy did not vanish. Pius II tried to condemn appeals from pope to council, but opponents of reigning popes still appealed to future councils. ${ }^{3}$ In 1511, dissident cardinals even summoned a council at Pisa in opposition to Julius II, the warrior pope. ${ }^{4}$ Pope Julius, in reply, summoned the Fifth Lateran Council (1512-17) which frustrated the Pisan assembly but failed to effect sufficient reform of the church. ${ }^{5}$ This crisis, atop the heritage of Constance and Basel, left the papacy averse to holding councils, especially those not tightly controlled by Rome, even when the lack of acceptable reform left Catholicism vulnerable to challenges from Martin Luther and other reformers. ${ }^{6}$ To make matters more complex, Luther and his Catholic opponents argued over how to gather a widely-accepted council to restore unity to the church. Each side wanted to define a council in such a way as would support its cause. ${ }^{7}$

1378-1460: The Conciliar Response to the Great Schism (New York: St. Martin's, 1977), 82-83, 128-29. For the long debate over the validity of Haec sancta, see Francis Oakley, The Conciliarist Tradition: Constitutionalism in the Catholic Church, 1300-1870 (Oxford: Oxford University Press, 2008).

2. Stephen E. Lahey, John Wyclif (Oxford: Oxford University Press, 2009), 29, 102, 224; Thomas A. Fudge, The Trial of Jan Hus: Medieval Heresy and Criminal Procedure (Oxford: Oxford University Press, 2013), 238-95.

3. Defensorium obedientiae apostolicae et alia documenta, ed. Heiko Oberman, Daniel E. Zerfoss, and William J. Courtenay (Cambridge, MA: Belknap Press, 1968); Hubert Jedin, A History of the Council of Trent, trans. Ernest Graf, vol. 1 (London: Thomas Nelson and Sons, 1957).

4. Augustin Renaudet, Le concile Gallican de Pise-Milan (Paris: Honoré Champion, 1922).

5. Nelson H. Minnich, "The Healing of the Pisan Schism (1511-13)," Annuarium Historiae Conciliorum 16 (1984): 59-192; Nelson H. Minnich, "Luther, Cajetan and Pastor Aeternus (1516) of Lateran V on Conciliar Authority," in Martin Luther in Rom: Die Ewige Stadt als kosmopolitisches Zentrum und ihre Wahrnehmung, ed. Michael Matheus, Arnold Nesselrath, and Martin Wallraff (Berlin: De Gruyter, 2017), 187-204.

6. Thomas M. Izbicki, “The Papacy's Aversion to Councils in the Time of Leo X: Leipzig in the Context of Conciliarism” (forthcoming).

7. Scott Hendrix, Luther and the Papacy: Stages in a Reformation Conflict (Philadelphia: Fortress Press, 1981), 50-51, 154-55; David V. N. Bagchi, Luther's Earliest Opponents: Catholic Controversialists, 
Sixteenth-century Castilian Dominican theologians had to confront this thorny heritage. One factor in it was the papalist apologetic of the Castilian Dominican Juan de Torquemada (d. 1468), the chief apologist for Eugenius IV in his conflict with Basel. In his Summa de ecclesia (1453), Torquemada both defended the supremacy of the papacy over church councils and, more specifically, developed an argument against the validity of Haec sancta. ${ }^{8}$ His argument that Constance was not yet a legitimate general council in 1415, when the decree was issued, was adopted by Eugenius in his anti-conciliar bull Moyses vir Dei (1439). According to Torquemada, Constance was valid only later when the three obediences of the Schism were assembled at Constance. ${ }^{9}$

The issues raised by the Schism and the Conciliar Crisis (1439-49) were not lost on Francisco de Vitoria (d. 1546), the guiding light of the School of Salamanca, when he dealt with ecclesiological issues. Vitoria is best known for his contributions to the debate over the Spanish presence in the Indies and the origins of international law, but he addressed other issues too. He had studied in Paris, the seat of conciliarist theology, and kept the Parisian line of argument in mind, but critically, when dealing with the topic of ecclesiastical power. ${ }^{10}$ Vitoria composed two relectiones or public lectures on ecclesiastical power (1532-33) and a Relectio de potestate ecclesiae et concilii (1534), which dealt with conciliar authority. Vitoria was friendly to councils in some ways, but he had to approach them cautiously in the light of past controversies. ${ }^{11}$ If

1518-1525 (Minneapolis: Fortress Press, 1991), 70-77.

8. Thomas M. Izbicki, Protector of the Faith: Cardinal Johannes de Turrecremata and the Defense of the Institutional Church (Washington, DC: Catholic University of America Press, 1981). For the shaping of the reform agenda at Constance, see Phillip H. Stump, The Reforms of the Council of Constance (1414-1418) (Leiden: Brill, 1993).

9. Thomas M. Izbicki, “The Hand of Power for the Feeding of Christ's Sheep": The Pope and the Episcopate in Juan de Torquemada's Early Polemics," in Primato, pontificio ed episcopato dal primo millenio al Concilio Ecumenico Vaticano II: Studi in onore dell'Arcivescovo Agostino Marchetto, ed. Jean Ehret (Vatican City: Libreria Editrice Vaticana, 2013), 217-33.

10. See, among others, James Brown Scott, The Spanish Origin of International Law: Francisco De Vitoria and His Law of Nations (Oxford: Clarendon Press, 1934); Jacques Quétif and Jacques Echard, Scriptores Ordinis praedicatorum recensiti [...], 2 vols. (Paris: Apud J-B-Christophorum Ballard et Nicolaum Simart, 1719-21), 2:128-30.

11. Katherine Elliot Van Liere, "Vitoria, Cajetan, and the Conciliarists," Journal of the History of Ideas 58 (1997): 597-616, 598-99, 601. For summaries of these relectiones, see Ulrich Horst, Die Lehrautorität des Papstes und die Dominikaner-Theologen der Schule von Salamanca (Berlin: Akademie Verlag, 2003), 41-74. 
he exalted general councils, he could be opening the way to another challenge to the papacy at a time when he was addressing the threat of the Lutherans, the "modern heretics," to the Western church. (Vitoria called Martin Luther "the most impudent of all.") Also, attributing supreme power to the entire church, as represented by a council, might be taken by critics as adopting Luther's argument for "the priesthood of all believers." ${ }^{2}$

The first Relectio de potestate ecclesiastica focused mostly on the nature of ecclesiastical power, defense of the sacrament of penance, and the relationship between the spiritual and temporal powers in Christendom. The councils of the fifteenth century received little attention at first. Only when he addressed the immunity of the clergy from judgment by the temporal power did Vitoria touch on them. The question was raised when referencing Juan de Torquemada's Summa de ecclesia and John XXII's condemnation of Marsilius of Padua. Vitoria dismissed the question of whether clerics were exempt by law from appearing before a secular judge - an immunity that Marsilius tried to weaken — as being too well known to require attention. To contradict the proposition, Vitoria cited the condemnation of John Wyclif by the Council of Constance: "The contrary opinion was among the theses of John Wyclif condemned at the Council of Constance."'13 (Later, in the Relectio de Indis, Vitoria cited the same condemnation at Constance to prove that the church did not require rulers to be Christians in a state of grace to exercise power legitimately. ${ }^{14}$ )

The second Relectio de potestate ecclesiastica, completed a year later, began with the question of whether this power belonged to the whole church, not just to individual members, an issue essential to the conciliarism of Constance and Basel: "First of all, we may put the question whether the power of the Church per se is vested in the Church as a whole? That is to say, in the universal Church as distinct from its individual members." ${ }^{15}$

12. Francisco de Vitoria, Political Writings, trans. Anthony Pagden and Jeremy Lawrence (Cambridge: Cambridge University Press, 1991), xiv, xvi-xvii, xxi-xxiii, 126-29, 141-42, at 126. Translated excerpts from the relectiones on ecclesiastical power are from this volume. All other translations are mine.

13. Relectiones theologicae R. P. Fr. Francisci Victoriae, 2 vols. (Madrid: Manuel Martin, 1765), 1:59. Vitoria, Political Writings, 101, restores the references to Torquemada and John XXII that had been replaced by a more general statement in the Madrid edition. For the condemnation of Wyclif, see Conciliorum Oecumenicorum Generaliumque Decreta 2, 1:550-58, 572-80.

14. Relectiones theologicae R. P. Fr. Francisci Victoriae, 1:191-93. Vitoria, Political Writings, 111, $240-42$.

15. Relectiones theologicae R. P. Fr. Francisci Victoriae, 1:67, "An potestas Ecclesiastica sit per se in tota Ecclesia, distinguendo Ecclesiam uniuersalem à singularibus personis." Vitoria, Political Writings, 111. 
Vitoria rejected any idea that the church received this power from lay rulers, arguing instead that Christ conferred it directly on Peter and the other apostles. This included the power to consecrate the Eucharist, which no community could grant, only God. Likewise, God gave it only to superiors in the church. This power differed from civil power: "Ecclesiastical power [...] is supernatural, and given for higher ends." ${ }^{16}$ Peter received special powers which made him Vicar of Christ. Only Christ, like a prince under Roman law, could confer this power on his legate or vicar:

And so, the conclusion is that, as the ruler of the Church does not derive His authority from the Church, nor does His vicar. [...] This is confirmed by the facts that the doctors and saints do not call the Supreme Pontiff "the Vicar of the Church," but "the Vicar of Christ."

Through him, as primate and prince, the governing power of jurisdiction, according to the Dominican cardinals Torquemada and Thomas de Vio (Cajetan), was received and transmitted to the other apostles, their successors being the popes and the bishops respectively. ${ }^{18}$ Vitoria conceded that ecclesiastical assemblies addressed important matters in the decrees they issued "in the name of the whole council." However, he said, a council by itself had no such power from divine law. It only had the collective power of the ecclesiastical authorities assembled together who willed to act as if one body:

Therefore, the whole council has greater power than the individual powers of the fathers who compose it. Hence this power is not immediately vested in the council by divine law, but it is conferred upon it by the will of the prelates who combine their authorities, as it were, in a single body.

16. Relectiones theologicae R. P. Fr. Francisci Victoriae, 1:71-72, 74, "sed potestas Ecclesiastica est supernaturalis, atque à Deo ad superiora datur." Vitoria, Political Writings, 116-17, 118-19 at 119.

17. Relectiones theologicae R. P. Fr. Francisci Victoriae, 1:73, "Ergo ad Christum tanquam ad Principem spectat ordinare de Legato, \& Vicario suo. [...] Et confirmatur hoc: Quia Doctores, \& Sancti non vocant Summum Pontificem Vicarium Ecclesiae, sed Vicarium Christi." Vitoria, Political Writings, 117-18 at 118. Vitoria depends especially on Cajetan in this context; see Van Liere, 602-03, 612-13.

18. Relectiones theologicae R. P. Fr. Francisci Victoriae, 1:94-95, 99-101, 104-06, describing the apostles' power in this matter as personalis. Vitoria, Political Writings, 136-38, 142-43, 149-50. Vitoria did allow for Peter and others being able to name their successors instead of their being elected by those of lesser rank. 
This was true whether the council was local or general. ${ }^{19}$ Vitoria also dismissed the comparison of pope to council as a hateful one (odiosa) in which he had no desire to share. ${ }^{20}$

It was in this context that Vitoria addressed briefly the claims to supreme ecclesiastical authority made by the councils at Constance and Basel. He was a near contemporary of those who had attended the council at Pisa and the Fifth Lateran Council. He was aware of the exchange of polemics between Cajetan and the Parisian doctors Jacques Almain and John Mair, in which the possibility that councils had power from the whole church superior to that of the pope was debated. ${ }^{21}$ Vitoria may also have been aware of the polemics about papal and conciliar power that arose in Germany beginning with the 1519 Leipzig debates involving Luther and John Eck. ${ }^{22}$

With these cases in mind, Vitoria argued that the assemblies at Constance and Basel advanced claims not made by more ancient councils. He even suggested that an error might have crept into the decrees of those more recent councils: "I should not be surprised if some error had crept into the form of words." ${ }^{23}$ Vitoria's larger conclusion was that a church, local or universal, did not need power directly from Christ: "it is not necessary for the church to have immediate authority from Christ." It sufficed for a church to have power "from its prelate, or from a council of prelates, or from the pope himself." ${ }^{24}$ Power came

19. Relectiones theologicae R. P. Fr. Francisci Victoriae, 1:78, "Et idèo nihil aliud posset totum Concilium, nisi quod ex potestatibus ejus singulis, \& illarum subjiectis consurgere potest. Unde haec potestas non est in Concilio immediatè Jure Divino, sed ex voluntate Praelatorum qui volunt ex seipsis unam auctoritatem, \& velut unum corpus constituere." Vitoria, Political Writings, 120-21.

20. Relectiones theologicae R. P. Fr. Francisci Victoriae, 1:77. Vitoria, Political Writings, 122 translates odiosa as "hotly-contested." Parisiensium is translated as "John of Paris," not, as is apparent, a reference to the doctors of the University of Paris.

21. Conciliarism and Papalism, trans. J. H. Burns and Thomas M. Izbicki (Cambridge: Cambridge University Press, 1997).

22. Scott Hendrix, Luther and the Papacy: Stages in a Reformation Conflict (Minneapolis: Fortress Press, 1981), 85-94; Thomas de Vio, Cajetan Responds: A Reader in Reformation Controversy, trans. Jared Wicks (Eugene, OR: Wipf and Stock, 2011), 105-44, 151-52.

23. Relectiones theologicae R. P. Fr. Francisci Victoriae, 1:76, "Hoc solùm reperitur in recentioribus Concilis [!], ut Basiliensis, Constantiensi, non autem in antiquis. Nec mirum est, si in modo loquendi erratum sit." Vitoria, Political Writings, 121.

24. Relectiones theologicae R. P. Fr. Francisci Victoriae, 1:80, "\& demum non oportet ad veritatem illorum verborum non oportet quod Ecclesia habeat immediatè authoritatem à Christo, sed satis est, quod 
to a church only through one of them. Even then Vitoria denied that the powers Christ gave the apostles at Matthew 18:18 for dealing with sins conferred power on the church or a council, even an assembly of priests and bishops. This left room for a general council to derive its power from the pope himself. ${ }^{25}$

Although he found comparing pope and council odious, Vitoria still discussed this matter in his 1534 relectio. The question he posed in that case was whether the pope could override the decrees of a council or dispense from them. He advanced an argument that the council was above the pope, who could not reverse its decrees. This opinion he described as communis opinio parisiensium, the common opinion of the doctors of the Sorbonne. ${ }^{26}$ Later he argued that Jean Gerson, a leader of the Council of Constance, was the only doctor of theology among the more recent ones who held this opinion. ${ }^{27}$ Vitoria also contrasted the opinion of the Thomists with the communis sententia Parisiensium and many others, including the canonist Panormitanus, who had supported the Council of Basel. However, Vitoria temporarily refused to take sides about the papal ability to dispense from the laws of general councils. ${ }^{28}$ When Vitoria discussed the topic in this relectio, the same ambivalence would emerge in his treatment of the papal power to dispense.

Vitoria's treatment of the issue of dispensation distinguished between "two types of canons," "duplex [...] genus canonum". The first type was grounded in divine law and, in some contexts, natural law: "[...] and one type of canons belong to divine law, like those which pertain to the articles of faith and the substance of the sacraments, and those things which have a necessary and obvious connection to divine or natural law, and pertain to good morals." ${ }^{29}$

habeat à suo Praelato: vel Praelatis congregatis, vel ab ipso Papa." Vitoria, Political Writings, 124.

25. Relectiones theologicae R. P. Fr. Francisci Victoriae, 1:80, an argument taken over from Cajetan; see Vitoria, Political Writings, 125.

26. Relectiones theologicae R. P. Fr. Francisci Victoriae, 1:138.

27. Relectiones theologicae R. P. Fr. Francisci Victoriae, 1:148, "licet sit solus unus Doctor Theologicus, scilicet Gerson inter recentiores, qui videtur dicere, quòd Papa non possit ferre leges obligatorias, nisi sequitur ex Iure divino, vel naturali." Vitoria also said Gersion infected others "with his poison," "suo veneno"; see Relectiones theologicae R. P. Fr. Francisci Victoriae, 1:153.

28. Relectiones theologicae R. P. Fr. Francisci Victoriae, 1:148.

29. Relectiones theologicae R. P. Fr. Francisci Victoriae, 1:139, " $\&$ unum genus canonum revera de jure divino, sicut qui pertinent ad Articulos Fidei, \& ad substantiam Sacramentorum, aut qui necessariam \& manifestam habent connexionem ad legem divinam, seu naturalem, \& pertinentia ad bonos mores." 
The pope had no power over any of these to dispense "and much less abrogate" them. Vitoria added, "because natural law is immutable," "quia jus naturale est immutabile." ${ }^{30}$ Both natural law and divine law, the foundations of these decrees, derived their force "from divine authority," "authoritate divina." Otherwise obeying them would not be obligatory. Moreover, no "human dispensation," "dispensatio humana" owed its force to superior, divine authority. ${ }^{31}$ However, Vitoria set up arguments for a papal ability to dispense in such matters, mentioning Cajetan's negative opinion on the divorce of Henry VIII, which defended the dispensation for the king to marry his brother's widow. ${ }^{32}$ The argument for such an ability was grounded on the lack of a divine prohibition against the Vicar of Christ issuing such dispensations. ${ }^{33}$ Vitoria concluded that there were circumstances for dispensations, but they did not touch the substance of a decree concerning faith or morals (sed non quantum ad substantiam suam). ${ }^{34}$ Vitoria said that the pope was Christ's legate and vicar, but He made His vicar the minister and steward of His laws, not one able to dissolve or relax them. The pope had "only their ministry and dispensation." ${ }^{35}$

Vitoria devoted the rest of the relectio to dispensations rooted not in divine law but instituted by human will: "Because he has the power of taking away what was introduced by the power and will of humanity." ${ }^{36} \mathrm{He}$ said both pope and council could interpret laws, declaring what was right, rather than change them: "Nevertheless, it pertains to the pope or a council to interpret and to declare what is right." ${ }^{37}$ Looking at dispensations, Vitoria was willing to see

30. Relectiones theologicae R. P. Fr. Francisci Victoriae, 1:139, "In hoc genere decretorum, aut canonum Papa nihil potest immutare dispensando, \& multo minus abrogando.”

31. Relectiones theologicae R. P. Fr. Francisci Victoriae, 1:140.

32. Relectiones theologicae R. P. Fr. Francisci Victoriae, 1:141. J. J. Scarisbrick, Henry VIII (Berkeley: University of California Press, 1968), 166-71; Cajetan Responds, 175-88.

33. Relectiones theologicae R. P. Fr. Francisci Victoriae, 1:141, "Sed non invenitur ubi sit prohibita haec dispensatio Papae: ergo."

34. Relectiones theologicae R. P. Fr. Francisci Victoriae, 1:142.

35. Relectiones theologicae R. P. Fr. Francisci Victoriae, 1:148, "Christus autem non concessit solutionem, aut relaxationem, sed solùm ministerium, \& dispensationem illorum...."

36. Relectiones theologicae R. P. Fr. Francisci Victoriae, 1:143, "Quia habet potestatem tollendi id quod per hominis potestatem [et] voluntatem inductum est."

37. Relectiones theologicae R. P. Fr. Francisci Victoriae, 1:147, "tamen ad Papam, vel Concilium spectat interpretari, \& declarare tale jus." 
the pope as the logical dispenser from laws when the Christian commonwealth had need, "when it is necessary in the republic," since councils rarely were held. Variations of challenges and times required this: ${ }^{38}$ "Since a council could dispense from its decrees, as it was able to do while in session, "therefore, the pope could do so too." ${ }^{39} \mathrm{He}$ argued that even a conciliarist like Panormitanus accepted some papal ability to dispense. ${ }^{40}$

Granting this power to general councils, Vitoria also had to contemplate the possibility of one issuing a decree not able to be dispensed, a decretum irritans, such as the Council of Basel considered imposing on Pope Eugenius IV. Vitoria referred to a work of Juan de Torquemada criticizing this proposal, although he had not actually seen it. ${ }^{41} \mathrm{He}$ also said that Christ had given the pope supreme power. A council could not create one more powerful. Such an attempt would be a sacrilege: "And it would be altogether a sacrilege to say that a council could establish in the Church some power superior to the pope, whom Christ established." 42 This allowed Vitoria to sustain the argument that the pope could dispense from its statutes even in the face of such a decree. ${ }^{43}$

Having affirmed the papal power to dispense, Vitoria tried to set limits on its exercise. He objected to how freely dispensations were being granted

38. Relectiones theologicae R. P. Fr. Francisci Victoriae, 1:149, "Si ergo hujusmodi dispensatio est necessaria in Republica, dicere quod solùm resideret in Concilio, absurdum est, cùm dispensationes sint necessariae ordinatae propter variationem causarum \& temporum. Concilium autem non saepe potest congregari. [...] Ergo oportet quod resideat in Papa" ("If, therefore, dispensation of this sort is necessary in the republic, it is absurd to say that [this power] might reside only in a council, since dispensations are necessary things ordained on account of variation of causes and times. A council, however, cannot be assembled often.... Therefore, it should reside in the pope").

39. Relectiones theologicae R. P. Fr. Francisci Victoriae, 1:149, "Cùm igitur Concilium posse dispensare in suis decretis, ergo etiam Papa poterit."

40. Relectiones theologicae R. P. Fr. Francisci Victoriae, 1:153-54.

41. Relectiones theologicae R. P. Fr. Francisci Victoriae, 1:152, "Sed illum librum ego invenire non potui," "But I could not find that book."

42. Relectiones theologicae R. P. Fr. Francisci Victoriae, 1:150, "\& omnino esset sacrilegium dicere, quòd Concilium possit constituere in Ecclesia aliquam potestatem superiorem Papa, quem Christus constituit."

43. Relectiones theologicae R. P. Fr. Francisci Victoriae, 1:152, "Non obstante decreto irritante Concilii, Papa posset dispensare in statutis ejus" ("Not withstanding that annulling decree of the council, the pope could dispense in his statutes"). 
in his day (quotidie), even against the marital impediment of consanguinity. ${ }^{44}$ More pointedly, Vitoria objected to how widely the Roman Curia granted these privileges, to the point of scandalizing not just the humble but the great: "But we see daily in the Roman curia such broad, indeed entirely destructive dispensations granted that the world could hardly bear, scandalizing not just the humble but even the great." ${ }^{35}$ The theologian went on to argue for limits on dispensation. The seventh proposition in the relectio is that the pope is not permitted to dispense against conciliar decrees "by his whim and without a reasonable cause," even where the matter did not pertain to divine law. ${ }^{46}$ Any unreasonable and rash dispensations granted by the pope against observance of the laws, which "took away entirely or a great part of the observance of the laws" necessarily "verges on great harm to the Church." ${ }^{37}$ Although he did not use the term, Vitoria, like most theologians and canonists, believed the pope could not upset the status ecclesiae, the right order of the church..$^{48}$ Moreover, the pope was obligated to live by the laws. Although a prince and thus not bound by human laws, according to Thomas Aquinas who was following Digest 1.3.31, he was not freed from those laws "under God's judgment." ${ }^{49}$ Thus, these dispensations were to cover cases "not able to be foreseen by the legislator." ${ }^{50}$ These limits were binding not just by natural law "but even by positive law." ${ }^{51}$ Vitoria concluded

44. Relectiones theologicae R. P. Fr. Francisci Victoriae, 1:150.

45. Relectiones theologicae R. P. Fr. Francisci Victoriae, 1:154, "sed videmus quotidie à Romana Curia tam largas imò omnino dissolutas dispensationes profectas, ut orbis ferre non possit, nec solum in scandalum pusillorum, sed majorum."

46. Relectiones theologicae R. P. Fr. Francisci Victoriae, 1:154, "Non licet Papae dispensare in legibus \& decrettis Conciliorum pro suo arbitrio, \& sine causa rationabili, etiam ubi nihil continen (!) juris diuini.” See also Relectiones theologicae R. P. Fr. Francisci Victoriae, 1:157.

47. Relectiones theologicae R. P. Fr. Francisci Victoriae, 1:154, "Ergo si Papa per irrationabiles, \& temerarias dispensationes tollat vel omnino, vel ex magna parte legum observationem. hoc necesse est, ut vergat in detrimentum magnum Ecclesiae."

48. Yves Congar, "Status ecclesiae," in Congar, Droit ancienne et structures ecclésiales (London: Variorum, 1982), 1:3-31.

49. Relectiones theologicae R. P. Fr. Francisci Victoriae, 1:156, "Unde \& S. Thom. 12. q. 96. art. 5. ad 3. dicit quòd quam ad Dei judicium Princeps non est à lege solutus."

50. Relectiones theologicae R. P. Fr. Francisci Victoriae, 1:157, "Est enim, ut Doctores omnes dicunt, dispensatio quasi quedam interpretatio juris in casibus, quos Legislator videre non potuit."

51. Relectiones theologicae R. P. Fr. Francisci Victoriae, 1:158, "Nec solùm hoc est verum ex Jure Divino naturali, sed etiam de jure positivo." 
that, in certain cases, it was better not to dispense than "to bend the rigor of the law through dispensation." ${ }^{52}$ A council, like the pope, could determine which laws were not to be subject to dispensation: "And consequently it cannot prohibit the supreme pontiff to dispense in some case which arises." ${ }^{33}$ The council could not presume that in every case a dispensation was prohibited, because there might be an urgent reason for one. ${ }^{54}$ Vitoria also thought a pope could do things legally that, nonetheless, were done badly and not desirable. ${ }^{55}$ Vitoria concluded that there could be dispensations, because it was "safer and more just" that he not be bound "by some of the laws." ${ }^{6}$ They should occur, however, only for the common good (in bonum commune), not for private interests. ${ }^{57}$

Melchor Cano (d. 1560) succeeded Vitoria in his theological chair at Salamanca. He also became a theological adviser to King Phillip II of Spain (r. 1556-98). Writing in the time of the Council of Trent (1545-63), in the early sessions of which he had participated, he took a hard look at the fifteenthcentury councils. The fact that Cano was at Trent when there still was sentiment for a council including the Lutherans, and even more for undertaking widespread reforms ${ }^{58}$ may have influenced his stand against conciliarism. Thus, Cano would not ignore the potential of a conciliar challenge to the papacy when he composed his extensive De locis theologicis, even while he contemplated the increasing threat of Protestant movements in the North. ${ }^{59}$ Salamanca was

52. Relectiones theologicae R. P. Fr. Francisci Victoriae, 1:159, "Similiter profectò est in aliquibus legitus humanis, in quibus satius esset nunquam dispensare, quam illarum rigorem flectere per dispensationem."

53. Relectiones theologicae R. P. Fr. Francisci Victoriae, 1:160, "Concilium posset hoc declarare, \& determinare, \& etiam statuere, ut in tali lege nunquam dispensator [.... Item, quia Papa potest facere tale statutum, ergo etiam Concilium."

54. Relectiones theologicae R. P. Fr. Francisci Victoriae, 1:161, "\& per consequens non potest prohibere Summum Pontificem ne in aliquot casu emergenti possit dispensare" ("And as a consequence [a council] cannot prohibit the supreme pontiff from being able to dispense in a newly-arising case").

55. Relectiones theologicae R. P. Fr. Francisci Victoriae, 1:168.

56. Relectiones theologicae R. P. Fr. Francisci Victoriae, 1:166, "\& sic poterit fieri dispensatio sine violatione, \& dispensatione legis. Sed tutius \& justius videretur, ut fieret absoltè de aliquibus legibus."

57. Relectiones theologicae R. P. Fr. Francisci Victoriae, 1:167.

58. John W. O’Malley, Trent: What Happened at the Council (Cambridge, MA: Belknap Press, 2013), 73-126; Alain Tallon, La France et le Concile de Trente (1518-1563) (Rome: École Française de Rome, 1997), 83-115.

59. Melchor Cano, De locis theologicis, in R.D. Melchoris Cani, Ordinis Praedicatorum, Episcopi Canariensis, \& primariae Cathedrae in Academia Salmanticensi olim Praefecti Opera: quorum elenchum 
not walled off from Europe's larger ecclesiological currents, even under the Hapsburg kings; Cano, however, was more committed to papalism than was Vitoria.

Cano devoted two books to these issues in De locis theologicis. One, book 5 , was devoted to councils, while book 6 focused on the authority of the Roman church. In the fifth book, he treated the councils of Constance and Basel, while using the Council of Florence and the Fifth Lateran Council as counter examples to their conciliarism. ${ }^{60}$ Like Vitoria, Cano depended on Torquemada and Cajetan in his discussion of councils. ${ }^{61}$ His polemical targets in this case were the doctors of Paris, especially Jean Gerson and Jacques Almain, saying they were "especially the authors of this opinion." 62

For present purposes, we shall focus on Cano's extensive discussions of the councils of Constance and Basel. In the first case, he said that Constance claimed a council was superior to the pope, almost certainly a reference to the decree Haec sancta: "Besides, the Council of Constance defined a council to be superior to the pope." Cano cited the Council of Florence under Eugenius IV as contradicting this claim, probably a reference to the decree Moyses vir Dei, which rejected Haec sancta. He also cited Lateran V under Leo X in this context. ${ }^{63}$ Cano then cited the tres veritates of Basel (1439), which declared

vide pagina sequente: cum duplici indice, altero rerum ac sententiarum, altero locorum sacrae scripturae in hisce passim expositorum (Cologne: In officina Birckmannica, 1605). Cano criticized not just Luther but also Oecolampadius, Zwingli, Bucer, and Calvin; see Cano, De locis theologicis, 238, 248, 344. The book was first published after Cano's death; see Quétif and Echard, 2:176-78. Horst, 98-104.

60. Cano also cited Pius II's prohibition of appeals from pope to council; see Cano, De locis theologicis, 296.

61. See, for example, Cano, De locis theologicis, 255-56. Cano did say that he did not follow Torquemada in all things; see Cano, De locis theologicis, 261-62.

62. Cano, De locis theologicis, 303, "Inter Parisienses Gerson \& Almain huius sententiae praecipue auctores habetur." Horst, 101-02.

63. Cano, De locis theologicis, 238, "Praetereà, concilium Constantiense definit, concilium esse supra Papam, Florentinum autem sub Eugenio quarto, \& Lateranense sub Leone decimo, contrarium dogma finierunt: conciliorum érgo auctoritas infirmata est." See also Cano, De locis theologicis, 295, 296. For Moyses, see Conciliorum Oecumenicorum Generaliumque Decreta 2, 2:1218-24; Crowder, 172-77. Fifth Lateran issued two decrees cancelling the objectionable acts of the conciliabulum of Pisa; see Conciliorum Oecumenicorum Generaliumque Decreta 2, 2:1344-47, 1389-51. Leo X called Basel a conventicle or conciliabulum in Session 11; see Conciliorum Oecumenicorum Generaliumque Decreta 2, 2:1437-38. 
contradicting conciliar supremacy to be heretical. Basel also had asserted that the pope "could not transfer a council to another place or prorogue it at some time." Cano argued that no one since that date was crazy enough to believe that someone of an opinion contrary to Basel's decree was a heretic. ${ }^{64}$ Some believed any conciliar decree not confirmed by the pope was not binding, but others did not. ${ }^{65}$ He said that Constance began without papal authorization but was confirmed in part by Martin V. Basel was summoned by Eugenius IV but not confirmed by him. ${ }^{66}$

Melchor Cano both affirmed and denied the authority of Constance, depending on whether it affirmed orthodox doctrine and practice or contradicted papal supremacy. He was particularly concerned with the council's condemnation of communion under both species in Session 13. This decree was issued while Constance was without a universally recognized pope. The council, he thought, was without certain authority then, being "a mutilated council without a head." Only when Martin V, the undoubted pope, approved it was the decree on communion the act of a true general council: "[...] in the letters in which he approved the council." ${ }^{67}$ (This argument was followed in

64. Cano, De locis theologicis, 238-39, "Rursum concilium Basiliense definit, esse haereticum qui negauert, concilium esse supra Papam, aut asierunt Papam transferre in alium locum pose concilium, aut in aliud tempus prorogare. Et tamen nemo tamen insanus post ea tempora fuit, vt sententiae contrariae auctores hęreticos extimauerit: concilium ergo iudicia incertiora sunt, quàm vt certam fidem facere possint." For the tres veritates, see Conciliorum Oecumenicorum Generaliumque Decreta 2, 2:1064-65.

65. Cano, De locis theologicis, 246, "Hac diuisione posita \& omnium assensu approbata altera assumitur, Conciliorum siue generalium, siue prouincialium, seu episcopalium, quaedam esse congregata Romani pontificis auctoritate, alia verò non item. Rursum alia confirmata ab Eodem Romano Pontifice, alia verò non ab eo confirmata."

66. Cano, De locis theologicis, 246, "Basiliense quoque Eugenius quartus indixit, nec tamen confirmauit. At Constantiense, quamuis à principio nulli Romani pontificis auctoritate congregatum fuerit, confirmauit illud tamen Martinus quintus, pontifex maximus" ("Eugenius the Fourth began the Council of Basel, but he did not confirm it" But Constance, altough it was gathered from the beginning by the authority of no Roman pontiff, nevertheless it was confirmed by Martin the Fifth, supreme pontiff). Cano cited the condemnation of Second Ephesus in the Florentine bull of union with the Jacobites as showing a pope can refuse to confirm an erring council; see Cano, De locis theologicis, 248, 294.

67. Cano, De locis theologicis, 277-78, "Praetereà, concilium Constantiense, sess. 13, condemnat vt haereticos, eos qui dixerint, ecclesiam errare in consuetudine administrandi populo Eucharistiam sub vna specie tantùm. Ea Martinus quintus in litteris, quibus concilium approbauit, qui hoc ecclesiae institutum damnat, eos definit tanquam haereticos, vel sapientes haeresim, coercendos. Ecclesia igitur in motum huiusmodi iudicijs non errat, atque consequenti ne concilia quidem summi pontificis auctoritate 
context by Cano's restating Juan de Torquemada's rejection of Haec sancta as the act of a headless council. ${ }^{68}$ ) Martin V later had treated those who held this opinion on communion as holding an opinion that "smacked of heresy."

Cano gave such detailed attention to Pope Martin's confirmation of the acts of Constance because this related to the council's defense of orthodoxy, but it also allowed him to undermine Haec sancta. The confirmation had come about as the council was closing. The envoys of the king of Poland wanted Johannes de Falkenberg, the apologist for the Teutonic Knights in their Baltic crusade, condemned. The pope replied that he confirmed only what had been done conciliariter against heresy. ${ }^{70}$ This distinction between decrees about the faith and others allowed him to omit Haec sancta, enacted only by the followers of the Pisan pope John XXIII. The sessions that enacted it were without an undisputed head, and their decrees were not approved by Martin V. Thus Wyclif, Hus, and Jerome of Prague remained condemned, including for denying

fermata [...] Nam licet concilium Constantien. sess. 13. statuerit, eos pro haereticis condemnando, qui affirmarint, ecclesiam errare in modo communicandi plebem sub vna specie tantum at eo tempore statuit, quo sine capite erat. Contendit autem Caietan. in opusc. de auctoritat. Pap. \& con. \& in apolog. c. 20 \& 21. Turrecremata, item 3. lib. cap. 32. \& 33. concilium mutilum sine capite in decretis fidei ferendis nullam habere certam auctoritatem." For this condemnation, see Conciliorum Oecumenicorum Generaliumque Decreta 2, 1:563-64.

68. Thomas M. Izbicki, "Papalist Reaction to the Council of Constance: Juan de Torquemada to the Present," Church History 55 (1986): 7-20.

69. Cano, De locis theologicis, 277, 279. Cano did say that Martin, out of modesty, did not say those persons were guilty of outright heresy; see Cano, De locis theologicis, 278.

70. Cano, De locis theologicis, 294, "Quòd si obijcias, Martinum 5, in vltima sessio. Approbâsse omnia, et singula decreta in materijs fidei, quae prius à concilio Constantien. prodijssent: respondet idem Caietanus id propriè ad fidem pertinere, \& tamquam fidei decretum à Martino probari, quod aduersum haereticos fuisset definitum, vt in 8. 15. \& 21. sess. factum est. Quòd autem Martinus 5. ea solum probet, patet primum, quoniam ad petitionem oratoris regis Poloniae illa probatio facta est, qui hoc tantùm exigebat, vt acta in concilio contra haereticos confirmarentur. Patet etiam, quia Martinus dicit se omnia sic conciliariter facta approbare, \& non aliter acta." Frederick H. Russell, "Paulus Vladimiri's Attack on the Just War: A Case Study in Legal Polemics," in Authority and Power: Studies on Medieval Law and Government Presented to Walter Ullmann on His Seventieth Birthday, ed. Brian Tierney and Peter Linehan (Cambridge: Cambridge University Press, 1980), 237-54. Cano also said, in his Relectio de sacramentis in genere, that in the final session at Constance, Martin V affirmed that priests truly absolved sins; see Melchoris Cani episcopi Canariensis ex Ordine Praedicatorum [...] (Padua: Typis Seminarii, 1720), 485. 
that the pope is Vicar of Christ: ${ }^{71}$ but Haec sancta, once again, was deprived of authority. Moreover, following Cajetan, Cano argued that confirming the decrees not aimed at heresy would affirm the legitimacy of John XXIII, reviving the divisions of the Great Western Schism by rejecting Gregory XII and Benedict XIII and their followers: "This is nothing other than bringing back the old schism, condemning others who followed Benedict and Gregory." ${ }^{72}$ Cano also looked to Martin V's letters to inquisitors requiring suspected heretics to be asked if they accepted Constance's decrees about the faith, while also asking if they embraced the council itself as representing the church, to support his argument. ${ }^{73}$

Cano said he marvelled at "the blindness of those who wished to defend the Council of Basel." Eugenius IV had gathered the council, but thereafter he translated it to Ferrara and then to Florence. Basel was reproved after that by "the public authority of the Church." Cano contrasted the unions concluded at Florence with the Armenians and the Greeks with the effort of Basel to depose the pope. He added that the pope Basel had rejected was accepted by the church while the council's choice, Felix V, was held in contempt. ${ }^{74}$ The adherents of

71. Cano, De locis theologicis, 190B. Cano underlined the condemnation at Constance of the error of Wyclif and Hus that only the predestined belonged to the church; see Cano, De locis theologicis, 115.

72. Cano, De locis theologicis, 294-95, "Ad octauum ergo argumentum Caietanus in opusculo de auc. Pap. \& con. c. 8, respondit concilium Constantien. quo tempore illud decretum edidit, non fuisse vniuersale \& integrum. Erat enim tum schisma in ecclesia sub tribus pontificibus, Ioanne 23. Gregorio 12. \& Benedicto 13. Vnde asserere, quod id temporis illud concilium erat generale, nihil aliud est, quàm reuocare antiquum schisma, aliosque damnare, qui Benedictum \& Gregorium sequebantur. Quod tamen fuit, estque semper ambiguum [...]. Nam in illa 4. \& 5. sessione, vt idem Caietanus admonet, nec disputatio aut disquisitio aliqua intercesserat, nec defecti fuerant. Adhuc viri docti ad differendum \& tractandum ea, quae in fidei doctrina essent constituenda: sed id cautum postea à concilio fuit in sess. 6 . Ita si quis tradita in sess. 4. diligenter expendat, inuenit ea non formam habere decreti, quo videlicet aut fideles obligantur, aut contrarium sequientes explodantur. Patet demum ex literis Martini 5. in quibus errores Ioannis Wicleffi, Ioannis Hus, \& Hieronymi Pragensis extressè damnantur, nulla de ea re, an concilium sit supra papam, facta mentione." See also Cano, De locis theologicis, 311.

73. Cano, De locis theologicis, 250, 257, 278, 327. Cano also cited Martin's list of interrogations as affirming the superior jurisdiction of the pope and bishops over simple priests; see the Relectio de poenitentia in Melchoris Cani episcopi Canariensis ex Ordine Praedicatorum [...], 580.

74. Cano, De locis theologicis, 295, "In nono verò, mirror equidem illorum caecitatem, qui concilium Basiliense tueri volunt cùm manifestum sit. Illud, licet à principio Eugenio 4. consentiente fuerit congregatum, postea tamen ab eodem primùm Ferrariam, deinde Florentiam translatum, vbi Basileenses conatus publica ecclesiae auctoritate repressi sunt. Nam \& vnio Armenorum, \& Graecorum populi 
Eugenius the council, which favoured Hussite heretics, called heretics were accepted by the faithful, while the church treated Basel's adherents as heretics. ${ }^{75}$ Pope Nicholas V had realized that Felix was no true shepherd and that Basel was no true council. He regarded Eugenius, his predecessor, as "of happy memory."76 Cano argued that the letters of Eugenius and Cardinal Giuliano Cesarini, the papal legate, showed that the pope only approved continuation of the council, not its decrees. Moreover, the council was not legitimate in its second session, when the first anti-papal decree was issued: "The majority of the episcopate was absent" ("maior pars episcoporum deerat"). ${ }^{77}$

Cano's treatment of the Council of Basel was harsher than what he said about Constance, and he dealt intensively with the tangled conflict of that assembly with Eugenius IV and his Council of Florence. ${ }^{78}$ One of Cano's censures of Basel was its leadership. He particularly questioned the way in which Cardinal Giuliano Cesarini, the first president of the council, consented to a doctrine no theologian would think sound, believing heretics (probably a reference to the council's negotiations with the Hussites): "What [is it] that the legate Giuliano consented to the doctrine of the Council of Basel which no

\footnotetext{
Christiani consensione approbata, non in concilio Bassiliensi, sed in Floretino factum est. Et Eugenium ecclesia etiam post illam depositionis Basiliensi sententiam, pro vero pontifice habuit, Felicem autem illi illum in synodo electum contempsit" (For the union of the Armenians and Greeks approved with the consent of the Christian people was achieved not at the Council of Basel but in Florence. And the Church after Basel's sentence of deposition treated Eugenius as true Roman pontiff. It held Felix, elected in the synod, in contempt).

75. Cano, De locis theologicis, 295, "Quorsum ergo attinet mordicus concilium Basiliense tenere? Quorsum fauere haereticis, qui conciliorum in hereticos iudicia infirma esse contendunt, quod concilium Basiliense eos haeresis nomine damnârit, qui etiamnum catholici iudicantur?" (In what way, therefore, did the Council of Basel strive tenaciously to hold on? In what way did it befriend heretics, who contended that the judgments of those at the council were infirm, so that the Council of Basel called those heretics who are still regarded as Catholics).
}

76. Cano, De locis theologicis, 295, "Et Nicolaus 5. apertè sentit, Felicem illum non fuisse verum ecclesiae pastorem, sed nominatum. Nec verum concilium \& generale, sed congregatum vocat nomine concilii generalis. Eugenium verò felicis recordationis praedecessorem suum honorificentius appellat."

77. Cano, De locis theologicis, 296.

78. Cano also cited the Council of Florence as affirming that the seven sacraments confer grace, in the Relectio de sacramentis in genere, in Melchoris Cani episcopi Canariensis ex Ordine Praedicatorum [... ], 489, 490. See also Relectio de poenitentia, in Melchoris Cani episcopi Canariensis ex Ordine Praedicatorum [...], $521,537,539,540 \mathrm{~A}, 553,568,579$, discussing the sacrament of penance. 
theologian estimates [to be] so certain and solid, that he believed heretics who dissent from that doctrine?"79 Cesarini also had subscribed to the decrees of the council's second and third sessions which refused to yield to papal pressure to move to Bologna. "The legate subscribed to the error of others." This proved, to Cano's mind, that the pope had not just to summon a council but to review decrees to which his legates assented. ${ }^{80}$

Cano concluded his attack on Basel by citing at length the affirmation of the papacy by the Council of Florence in the decree of union with the Greeks. The pope, it said, held universal primacy as the successor of Peter in the role of Vicar of Christ. His role was to be the shepherd of all with "full power" ("plena potestas") from Christ to govern the church. This, Cano said, was evident from the records of all the ecumenical councils. He added that the pope was proven by theological reasoning to be unable to err when he judged concerning the faith: "when he judges about the faith, he cannot err."

Cano was a foe of fellow Dominican Bartolomé Carranza, who became archbishop of Toledo in 1557. When Carranza was accused of publishing heretical statements in his Commentary on the Christian Catechism (1558), two Salamancan friars, Cano and Domingo de Soto, were among those who examined the text and found errors in it. Cano's hostility to Carranza was such

79. Cano, De locis theologicis, 259, "Quid quod legatus Iulianus concilii Basileen. doctrinae consensit, quam nullus Theologus ita solidam \& certam existimat, vt haereticos credit, qui ab ea doctrina dissentiunt?" Gerald Christianson, Cesarini, The Conciliar Cardinal: The Basel Years, 1431-1438 (St. Ottilien: EOS Verlag, 1979).

80. Cano, De locis theologicis, 257, "Legatus demum pontificis aderat, cùm in secunda \& tertia sessione concilii Basiliensis vehementer erratum est, errori quoque caeterorum Legatus ipse subscripsit, non ergo satis est concilium esse coactum pontificis auctoritate, \& legatos concilii sententiam approbâsse, vt firma \& certa esse in ecclesia existimetur." Cano was kinder to the papal legates to the Council of Trent; see Cano, De locis theologicis, 258.

81. Cano, De locis theologicis, 322, "Praetereà, patres concilij Florentini, Definimus (inquiunt) sactam Apostolicam sedem, \& Romanum pontificem in vinuersum orbem tenere primatum: \& ipsum pontificem Romanum successorem esse B. Petri principis apostolorum, \& verum Christi vicarium, totiusque ecclesiae caput, \& omnium Christianorum patrem ac doctorem existere: \& ipsi in beato Petro pascendi \& gubernandi vniuersalem ecclesiam, à Domino nostro Iesu Christo plenam potestatem traditam esse: sicut in gestis Oecumenicorum conciliorum continenetur. Hactenus conciliorum testimonia satis multa retulimus, rationibus modò Theologicis ea, quae possuimus, corroboranda sunt: idque magis Romanum pontificem, cùm de fide iudicat, errare non posse." For a translation of this excerpt, see Crowder, Unity, Heresy and Reform, 171. Cano concluded that the evidence of councils proved "the Roman pontiff cannot err when he judges concerning the faith." 
that the archbishop named him to his judges as an enemy. ${ }^{82}$ The archbishop's case dragged on for years until he was required to renounce certain errors without suffering outright condemnation. ${ }^{83}$

A less noted work of Carranza addressed the powers of pope and council without becoming a focus of theological censure. ${ }^{84}$ It was, however, less firmly papalist than was the De locis of Cano, without being conciliarist in sentiment. The Summa omnium conciliorum of Carranza, first published in 1551, summarized papal history through to the reign of Paul III. The 1551 edition includes a prefatory letter by Carranza saying he intended to make the examples of past councils available to a future council addressing the needs of the church. Addressing the Great Western Schism and its aftermath, Carranza treated the period from the death of Gregory XI through the reign of Martin V in slightly more than a page. He noted that the popes of the schism launched censures at each other, but the division of the church lasted to the Council of Constance. The Council of Pisa tried to depose the Avignon and Roman claimants, electing Alexander V in their place, without achieving ecclesiastical union. Constance itself is described as successfully ejecting three men from the pontificate (Sunt autem tres hi partier in eo concilio dejecti). ${ }^{85}$

Carranza's summary of the acts of Constance claims that the council is called ecumenical because of its work of union: "This council was ecumenical because it was inaugurated to take away schism from the universal Church." ${ }^{86}$ Like Melchor Cano, his foe, Carranza cited the Council of Florence and the Fifth Lateran Council as contradicting Constance when it pronounced on the authority of councils (de auctoritate conciliorum). He also cited John and

82. This tangled personal history is treated by Tellechea Idígoras, "Melchor Cano y Bartolomé Carranza: Does Dominicos frente a frente ${ }^{*}$, Hispania Sacra 15 (1962): 1-89.

83. José Ignacio Tellechea Idígoras, Melanchton y Carranza: préstamos y afinidades (Salamanca, Universidad Pontificia, Centro de Estudios Orientales y Ecuménicos Juan XXIII, 1979). Quétif and Echard, 2:236-43.

84. Bartolomé Carranza, Summa omnium conciliorum et pontificum a Petro usque Paulum III (Paris: Petrus Delaulne, 1678). Earlier editions appeared in 1551 (Salamanca), 1564 (Paris), 1569 (uncertain location), 1576 (Antwerp), 1600 (Geneva), and 1659 (Douai). Horst, 91-97.

85. Carranza, Summa Conciliorum et Pontificum, 562-63.

86. Carranza, Summa Conciliorum et Pontificum, 564, "Hoc concilium fuit oecumenicum, propter materiam schismatis tollendi universam Ecclesiam concernentem inductum fuerat." 
Gregory, even Benedict (!), as having ceded their claims per se vel procuratores suos legitimos. ${ }^{87}$

Nevertheless, treating highlights of the Council of Constance, Carranza summarized accurately the sessions that issued the decree Haec sancta. ${ }^{88}$ This brief summary is followed in later editions by a long interpretative annotation by Franciscus Sylvius, a theologian from the University of Douai, making Carranza's history more thoroughly papalist. The addition cites Torquemada and other writers as limiting Haec sancta to times in which no one is certain who is the true pope. It also claims that Martin V did not confirm that decree, as he did the condemnations of Wyclif and Hus and the acts deposing rival claimants to the see of Peter. ${ }^{89}$ In a time of schism, a council could decide without defining a new dogma about councils, as Constance did to end the schism: "It could, nevertheless, judge in a time of schism who was true pope and provide the Church with a true pastor, when there is none or a doubtful one, which the Council of Constance rightly did." ${ }^{\prime 0}$ Constance rejected all claimants to the papacy. To do otherwise would have been "worthless and inane," taking sides in the schism. ${ }^{91}$

There follow summaries by Carranza of sessions that issued the decree rejecting communion under both species (session 13), accepted Gregory XII's resignation (session 14), and condemned articles of Jan Hus (session 15). He also summarized the concluding sessions of the council (sessions 39, 40, 41, 43, and 45), the last of which accepted only decrees enacted conciliariter. ${ }^{92}$ Martin V's bull Inter cunctas, condemning the errors of Wyclif and Hus, concludes Carranza's examination of the Council of Constance. ${ }^{93}$

The same pattern appears in this edition of Carranza's account of the councils of Basel and Florence, his own text being followed by annotations that

87. Carranza, Summa Conciliorum et Pontificum, 564.

88. Carranza, Summa Conciliorum et Pontificum, 564-65.

89. Carranza, Summa Conciliorum et Pontificum, 565-69.

90. Carranza, Summa Conciliorum et Pontificum, 565, "sed tantum in casu, id est, in tempore schismatis quoniam nesciunt quis sit verus papa"; and 565-66, "non possit definire nova dogmata fidei; potest tamen iudicare tempore schismatis, quis sit verus papa, \& providere Ecclesiae de vero Pastore, quando is nullus, aut dubius, quod recte fecit concilium Constantiense."

91. Carranza, Summa Conciliorum et Pontificum, 569, "Si contrarium fiat, id ipsum sit irritum \& inane." 92. Carranza, Summa Conciliorum et Pontificum, 569-76.

93. Carranza, Summa Conciliorum et Pontificum, 576-78. 
made the text more acceptable to the professors of the Sorbonne. ${ }^{94}$ Carranza's treatment of the Council of Basel briefly summarized its history from the beginning to session 39, which "deposed" Eugenius IV, including the election of the antipope Felix $\mathrm{V}^{95}$ Some sessions are discussed, whereas others are omitted or dismissed with a few words. The constitutions concerning the Jews, clerical concubines, and annates and the errors of the theologian Agostino Favaroni are treated at greatest length. ${ }^{96}$ An addition denies the authority of Constance and Basel except where a pope, Martin V or Nicholas V, confirmed their decrees: "they have no force unless perhaps what was approved in a bull of Martin V or Nicholas by pontifical authority." ${ }^{\text {"7 }}$ Attention then shifts to the Council of Florence, especially the decrees of union with the Greeks, Jacobites, and Armenians. ${ }^{98}$ Thereafter, Carranza shifts back to the deeds of the Roman pontiffs and significant events like the fall of Constantinople in 1453 and the canonization of Catherine of Siena. ${ }^{99}$

Carranza treated the Fifth Lateran Council in the reigns of Julius II and Leo $\mathrm{X}$, including the fact that it was convoked in reply to the 1511-13 conciliabulum of Pisa, summoned after Julius failed to call a council pro reformatione Ecclesiae, as he had promised. Julius opened the assembly, calling upon it to treat reform, schism, the Ottoman threat, and peace among Christians. ${ }^{100}$ This account includes measures against the assembly at Pisa and some reforms. Particular attention is paid to the decree issued by Leo $\mathrm{X}$ in session 19 defending belief in the immortality of the soul. ${ }^{101}$ Likewise, attention is given to the decree issued in Leo's session ratifying montes pietatis as licit. ${ }^{102}$ Carranza's account of the

94. See the Approbatio in Latin and French following the Praefatio.

95. Carranza, Summa Conciliorum et Pontificum, 579.

96. Carranza, Summa Conciliorum et Pontificum, 579-87. The additions at 588-90 defend adding the filioque to the Nicene Creed and the doctrine of Purgatory.

97. Carranza, Summa Conciliorum et Pontificum, 587, "Quae in his duabus congregationibus Constantiensi \& Basiliensi statuta sunt, non habent aliquod authoritatis robur, nisi dumtaxat illa quae in bullâ Martini 5. aut Nicolai 5. pontificiâ authoritate probata sunt." There follows (587-88) a summary of Eugenius IV's pontificate and the principal points of the Florentine decree of unity with the Greeks.

98. Carranza, Summa Conciliorum et Pontificum, 588-96.

99. Carranza, Summa Conciliorum et Pontificum, 597.

100. Carranza, Summa Conciliorum et Pontificum, 602.

101. Carranza, Summa Conciliorum et Pontificum, 602-10, 604-05.

102. Carranza, Summa Conciliorum et Pontificum, 607-08. 
concluding session underlines the fact that all the decrees were approved by Pope Leo, once he had dismissed it-an example of how Cano and Carranza thought a council should end. ${ }^{103}$ This account of the Lateran council ends with a transition to events from the beginning of the Reformation and through to the election of Paul III. ${ }^{104}$

Although Vitoria was mildly friendly to councils and critical of the Roman Curia, as we have seen, his successors, beginning with Cano and even Carranza, became increasingly hostile to the fifteenth-century councils. Spanish opinion was becoming closed against doctrinaire conciliarism, as it had against Protestantism. ${ }^{105}$ Constance was accepted best when it affirmed orthodox teachings. Martin V, these writers and their successors said, had accepted some decrees and ignored others, invalidating Haec sancta by not confirming it. Basel was treated as valid only where Eugenius confirmed it, and its continuation at the more fruitful council at Florence was underlined. Likewise, the Fifth Lateran Council was treated both as affirming sound doctrine and attempting reform, serving as a model of how a council should be held, ending with its decrees confirmed by a pope. Overall, as the Praeludium to Carranza's book argues, these men thought the council depended on the pope, who summoned it, not vice versa. Even if He returned to earth, Christ's authority would not depend on a council. His vicar too depended directly on Christ, not on a general council. ${ }^{106}$ Moreover, a council's decrees, its "sanctions," have no power unless confirmed by the supreme pontiff: "They have their power only from his authority"107

103. Carranza, Summa Conciliorum et Pontificum, 610, "Hac sessione absolutum est concilium \& confirmatum: \& probata universa \& singula quae definite sunt in concilio per Leonem decimum," "in this session the council was completed and confirmed; and all and everything which were defined were approved by Leo X."

104. Carranza, Summa Conciliorum et Pontificum, 610-11. The edition best available to the author includes the first nine sessions of the Council of Trent, whereas the 1551 edition concludes with the seventh session.

105. On the later writers of the Salamanca school, including Domingo Báñez, see Horst, 119-86.

106. Carranza, Summa Conciliorum et Pontificum, 4, "Ex eo patet, quod Sum. Pontifex Christi Servatoris sit Vicarius; \& quia si adhuc Christus in terris viveret, à Concilio Christi authoritas non penderet; sed supra omne Concilium esset, Papae authoritas Christi Vicaria à solo Christo pendet, à Concilio non dependet" (From this it is clear that the supreme pontiff, Christ's servant, is His vicar; and if Christ still lived on earth, the authority of Christ would not depend on the council. But the power of the pope as Christ's vicar, above every council, depends on Christ alone, not on the council).

107. Carranza, Summa Conciliorum et Pontificum, 5, "Nec Conciliorum sanctiones valent nisi à Summo Pontifice confirmatae; ab ejus siquidem authoritate robur habent" (Nor do the laws of councils have 
The classic exposition of this line of argument, extending even to limiting the list of officially recognized general councils, can be found in the Controversiae of the Jesuit cardinal Robert Bellarmine. First publishing this work in 1581-93, Bellarmine defended all aspects of post-Tridentine orthodoxy against the Protestants, especially against John Calvin, leaving no room for concessions or ambiguity. Among the theologians on whom the Jesuit cardinal relied were Torquemada, Vitoria, Cano, and Domingo de Soto. ${ }^{108}$ Bellarmine's classification of councils accepted Constance when it supported orthodoxy against Wyclif, Hus, and others who had erred in faith. ${ }^{109} \mathrm{He}$ also was able to cite Martin V's confirmation of the decrees of Constance on matters of faith as examples of canons condemned by Protestants but embraced by Catholics. Basel was largely rejected in favour of the pro-papal assemblies at Florence and the Lateran. Likewise, he embraced the papally-sponsored Council of Trent. This classification of councils would endure in Catholic circles well into to twentieth century. ${ }^{110}$

Torquemada was especially useful to Bellarmine when claiming superiority of the pope over the council. He was able to cite the Summa de ecclesia in a

validity unless confirmed by the supreme pontiff; indeed they have force from his authority). Domingo Bañez expressed trust in the judgment of a general council in matters of faith, but he still expected a pope to ratify conciliar decrees and oblige his successors to those concerning the faith; see Horst, 149-55. Bañez based his arguments on the works of Torquemada, Cajetan, and anti-Lutheran apologists (Horst, 127).

108. See, for example, Disputationum Roberti Bellarmini [...] De controversiis christianae fidei adversus hujus temporis haereticos tomus primus in Roberti Cardinalis Bellarmini opera omnia [...], 5 vols. in 4 (Naples: apud Josephum Giuliani, 1856-62), 1:308-09, 317, 525, 531. Bellarmine also made use of Cajetan's defense of the papacy; see Disputationum de controversiis christianae fidei, 1:309, 338.

109. Disputationum de controversiis christianae fidei, 1:309, 322. The latter reference was part of an argument against John Calvin that presbyters and bishops were not equal in the Primitive Church. Bellarmine denounced, alongside the various Reformers, the errors of Wyclifites and Hussites (Wiclefistas \& Hussitas); see Disputationum de controversiis christianae fidei, 21-22.

110. Disputationum de controversiis christianae fidei, 1:482, "Addo etiam duorum pontificum testimonia, quae etsi ab haereticis contemnuntur, tamen a catholicis cum honore recipienda sunt. Unum est Martini papae V. qui in bulla, quam edidit, concilio constantiensi approbante, haereticos haberi censuit eos, qui de sacramentis, aut fidei articulis aliter sentiunt, quam romana Ecclesia sentiat" (I add that the witness of two pontiffs, which is despised by heretics, nevertheless, must be received with honor by Catholics. One is the witness of Martin V, who in a bull he issued confirming the Council of Constance, judged to be heretics those who thought otherwise about the sacraments and the articles of faith than the Roman church thinks). 
long list of writings friendly to the papacy, including those of Thomas Aquinas and Cajetan. ${ }^{111}$ The Jesuit so relied on his Dominican predecessor that he referred his readers to the Summa de ecclesia for details of a properly conducted council. ${ }^{112}$ Bellarmine made special use of Torquemada's argument that the Council of Constance was assembled from only one obedience of the schism when it claimed supreme power in matters of faith, unity, and reform. He also denied that Martin V confirmed the decree Haec sancta, which contained that claim. ${ }^{113}$ Likewise, Bellarmine cited Torquemada to prove that Constance could act against one not considered a legitimate pope, although it could not have acted against a legitimate one: "For a doubtful pope is held not to be pope, and thus [the council] has power over him, [but] is not to have power over a [true] pope. Thus Torquemada [says]." ${ }^{114}$ Likewise, Bellarmine cited Torquemada in support of his contention that a bad pope could be resisted if he attempted to destroy the church. ${ }^{115}$

Following this line of thought pioneered by Torquemada, as said above, Robert Bellarmine presented a polemical but historical perspective on general councils. The Controversiae includes lists of councils approved, reproved, or partly accepted. The Council of Florence and the Fifth Lateran, both previously lauded by Melchor Cano, found places among the entirely accepted councils. ${ }^{116}$ The 1511-13 conciliabulum of Pisa was among those entirely reproved. ${ }^{117}$ Matters inevitably got more complicated with the councils of Constance and Basel. Bellarmine presented an argument that all decrees of Constance pertained to the faith, including Haec sancta. To deny one was to deny all. Even Haec sancta seemed to pertain to the faith: "This decree, however, seems to

111. Disputationum de controversiis christianae fidei, 1:64.

112. Disputationum de controversiis christianae fidei, 1:37.

113. Disputationum de controversiis christianae fidei, 1:71. Bellarmine added, loc. cit., a claim that both John XXIII and Gregory XII resigned without being deposed.

114. Disputationum de controversiis christianae fidei, 1:71, "Nam dubius papa habetur pro non papa, et proinde habere super illum potestatem, non est habere potestatem in papam. Ita Turrecremata" (For a doubtful pope is regarded as no pope, and thus to have power over him is not to have power over a pope. Thus Torquemada says).

115. Disputationum de controversiis christianae fidei, 1:71.

116. Disputationum de controversiis christianae fidei, 1:18.

117. Disputationum de controversiis christianae fidei, 1:18. 
pertain to the faith." ${ }^{118}$ The cardinal denied, in reply, the claim of Constance that it was superior to the pope. In fact, this pretension, he said, was "reproved at the Council of Florence and Lateran [Council]." Nor was Haec sancta a matter of faith. Martin V approved other decrees concerning the faith, the condemnations of Wyclif and Hus, which were made conciliariter. (Also, the last sessions were held in his presence.) Thus, only certain aspects of Constance were accepted by all Catholics. ${ }^{119}$

Basel was treated, inevitably, more harshly. That council began legitimately, but its anti-papal decrees were reproved by Eugenius IV, Nicholas V, and the Fifth Lateran Council. (Bellarmine added that Constance, in contrast, could not define dogma with no true pope in charge, but it could act to give the church a true shepherd. ${ }^{120}$ ) The Jesuit cardinal added, moreover, that God inflicted a severe sentence on the council, an outbreak of plague in Basel. ${ }^{121}$ Felix V was an antipope, created by the Basel assembly when it was "in schism"; and, in the long run, he resigned his pretended papacy to the true pope. Pope Nicholas then approved some decrees about benefices, but only "for the sake of unity and peace." Otherwise Basel was reproved by the Fifth Lateran Council. ${ }^{122}$

118. Disputationum de controversiis christianae fidei, 1:71, "hoc autem decretum ad fidem pertinere videtur."

119. Disputationum de controversiis christianae fidei, 1:19, "Quintum est concilium constantiense Patrum ferre mille, ex quibus episcopi amplius 300. Anno 1414. inchoatum sub Joanne XXIII. et anno 1418. Finitum sub Martino V. et Sigismundo imperatore. Plat. Palmerius dicit, quod hoc concilium quantum ad primas sessiones, ubi definit concilium esse supra papam, reprobatum est in concilio Florentino, et lateranensi ultimo: quantum ad ultimas sessiones, et ea omnia quae probavit Martinus V. ab omnibus catholicis recipitur." See also Disputationum de controversiis christianae fidei, 1:171, "Itaque cum confirmavit decreta de fide conciliariter conclusa, intelligebat tantum de damnatione Wiclefi et Hus" (And so when he confirmed the decrees concerning the faith arrived at in a conciliar manner, he understood this only of the condemnation of Wyclif and Hus).

120. Disputationum de controversiis christianae fidei, 1:103.

121. Disputationum de controversiis christianae fidei, 1:71-72. Bellarmine added that Felix V ceded his claim to the papacy to Nicholas; see Disputationum de controversiis christianae fidei, 1:72. He cited an argument of Calvin that Rome and its adherents were not in the true church after Eugenius was deposed and then reclaimed his see; see Disputationum de controversiis christianae fidei, 1:101. Bellarmine replied that Basel was only a seditious conciliabulum when it acted against Eugenius, who remained true pope (1:102).

122. Disputationum de controversiis christianae fidei, 1:19, "Sextum est concilium Basiliense inchoatum anno 1431. et continuatum Basiliae, ac deinde Lausannae usque annum 1449. Quo tempore cessit Nicolao V. pontifici, tam concilium, quam papa Felix V. in schismate ab ipso concilio creatus. Vide 


\section{Bellarmine added that the whole church rejected Basel by continuing acceptance} of Eugenius IV after the council decreed his deposition. Then he pointed once more to Felix V's abdication and Basel's eventual submission to Nicholas V while the council was resident in Lausanne. ${ }^{123}$

The 1409 Council of Pisa fell into the indefinite category. Antoninus of Florence had regarded it as "an illegitimate conventicle." Bellarmine was more hesitant. One reason he was unwilling to condemn that council was that it would make Alexander V and John XXIII, the Pisan popes, illegitimate, whereas they were widely regarded in the communis opinio as legitimate Roman pontiffs. $\mathrm{He}$ noted that Alexander VI took that number because he regarded Alexander V as a true pope. That made John, his successor, also a true Roman pontiff. ${ }^{124}$ Bellarmine added an admission that the work of Pisa and Constance to end the Great Western Schism was a proof that councils were useful to the church. ${ }^{125}$

acta concilii, et bullam annexam Nicolai V. pontificis. Hujus concilii nihil est ratum et probatum, nisi quaedam dispositiones circa beneficia ecclesiastica quae a concilio factae fuerant, quas (pacis et unitatis gratia) Nicolaus praedictus approbavit. Concilium vero ipsum reprobatur in concilio lateranensi ultimo, sess. 11." Bellarmine added elsewhere that Nicholas confirmed a decree about ecclesiastical censures; see Disputationum de controversiis christianae fidei, 1:71. Bellarmine compared Basel with the erring Second Council of Ephesus in Disputationum de controversiis christianae fidei, 1:66.

123. Disputationum de controversiis christianae fidei, 1:72A-B, "item Ecclesia tota, quae Eugenium a basileensibus depositum, semper habuit pro vero pontifice; denique basileenses ipsi, et papa Felix, quem ipsi creaverunt; Nam papa Felix tandem cessit Nicolao Eugenii successori et basileenses qui lausannam concilium transtulerant, tandem sese Nicolao subjecerunt, ut in eadem Bulla Nicolaus testatur" (Likewise, the whole Church regarded Eugenius, whom those at Basel deposed, as the true pontiff. Finally, even those at Basel and Felix, whom they made pope, agreed. In the end, Pope Felix submitted to Nicholas, the successor of Eugenius; and those of Basel, who had transferred the council to Lausanne, at last submitted themselves to Nicholas, as Nicholas testifies in that bull).

124. Disputationum de controversiis christianae fidei, 1:19, "Generale nec approbatum, nec reprobatum, videtur esse concilium pisanum, quod anno 1409. deposuit Gregorium XII. et Benedictum XIII. et elegit Alexandrum V. Siquidem s. Antoninus 3. par. tit. 22. cap. 5. \$2. et 3. summae historialis. asserit. Conciliabulum illegitimum, non verum Ecclesiae concilium fuisse, et eventus idem ostendisse videtur. Coactum enim concilium fuit ad schisma tollendum, et illud non sustinuit, sed auxit. Si autem sine dubio fuisset reprobatum, etiam sine dubio Alexander VI. se non sextum, sed quintum appellasset. Adde, quod est ferme communis opinio, Alexandrum, et qui ei successit, Joannem fuisse vero pontifices. At certe ex tribus, qui tum se pro pontificibus gerebant, isti maxime ut veri pontifices gerebant."

125. Disputationum de controversiis christianae fidei, 1:20. Bellarmine cited session 8 of Constance, which condemned Wyclif for denying the validity of the papacy, to prove that the pope is Vicar of Christ; see Disputationum de controversiis christianae fidei, 1:66. The cardinal also cited Martin V's bull Inter 
This categorization by Bellarmine, based on past writings, including by Spanish theologians, predominated in pro-papal Roman Catholic historiography down to the mid-twentieth century, when the Second Vatican Council reopened questions about the fifteenth-century councils. That council brought the issue of conciliar authority, once thought long dead, to the fore once again. ${ }^{126}$

cunctas, requiring that suspected heretics be asked whether they believed the Roman pontiff was head of the church; see Disputationum de controversiis christianae fidei, 1:68.

126. Alberto Cadili, "The Legacy of the Council," in Companion to the Council of Basel, ed. Michiel Decaluwé, Thomas M. Izbicki, and Gerald Christianson (Leiden: Brill, 2016), 471-501; Oakley, The Conciliarist Tradition, 257-69; Francis Oakley, "The Conciliar Heritage and the Politics of Oblivion," in The Church, the Councils and Reform: The Legacy of the Fifteenth Century, ed. Gerald Christianson, Thomas M. Izbicki, and Christopher M. Bellitto (Washington, DC: Catholic University of America Press, 2008), 82-97. For an example of traditional historiography of the councils, see Philip Hughes, The Church in Crisis: A History of the General Councils, 325-1870 (Garden City, NY: Hanover House, 1960), which omits Pisa and treats Basel-Ferrara-Florence as continuous, rather than in competition. 